\title{
BUKU AJAR BAHASA INDONESIA BERBASIS JENDER SEBAGAI MEDIA PENGEMBANGAN KARAKTER SISWA
}

\author{
Lilik Wahyuni, Endang Sumarti, dan Rokhyanto \\ FISH IKIP Budi Utomo Malang \\ email: lilik.wahyuni@ymail.com
}

\begin{abstract}
Abstrak
Penelitian pengembangan ini bertujuan menghasilkan buku ajar bahasa Indonesia berbasis jender yang difokuskan pada: (1) karakter yang dikembangkan dalam buku ajar bahasa Indonesia berbasis jender, (2) materi pembelajaran bahasa Indonesia berbasis jender, dan (3) struktur buku ajar bahasa Indonesia berbasis jender. Rancangan penelitian menggunakan model Dick, Carey, dan Carey yang dimodifikasi berdasarkan keperluan pengembangan. Hasil penelitian sebagai berikut. Pertama, karakter yang dikembangkan dalam buku ajar bahasa Indonesia berbasis jender adalah siswa yang mampu mengakses, berpartisipasi, mengontrol, memanfaatkan praktik kehidupan tanpa membedakan jenis kelamin. Kedua, materi pembelajaran bahasa Indonesia berbasis jender dikembangkan sesuai dengan nilai-nilai jender dan nilai-nilai matapelajaran bahasa Indonesia. Ketiga, struktur buku ajar bahasa Indonesia berbasis jender harus memperhatikan: (1) struktur tampilan, (2) struktur bahasa, (3) keterpahaman, (4) struktur stimulan, (5) struktur teks (keterbacaan), dan (6) struktur materi instruksional.
\end{abstract}

Kata kunci: buku ajar, berbasis jender, karakter, materi pembelajaran

\section{A GENDER-BASED INDONESIAN TEXTBOOK AS MEDIA TO BUILD STUDENTS' CHARACTER}

\begin{abstract}
This research and development study aims to produce a gender-based Indonesian textbook focusing on: (1) the character to build through a gender-based Indonesian textbook, (2) gender-based Indonesian learning materials, and (3) the structure of a genderbased Indonesian textbook. The research design was the model by Dick, Carey, and Carey, modified on the basis of the development needs. The results of the study are as follows. First, the character to build in the gender-based Indonesian textbook is that the students are able to access, participate in, control, and make use of life practices regardless of gender. Second, the gender-based Indonesian learning materials are developed in accordance with gender values and those of the Indonesian language subject. The structure of the gender-based Indonesian textbook should take account of: (1) the presentation structure, (2) the language structure, (3) the comprehensibility, (4) the stimulant structure, (5) the text structure (readability), and (6) the instructional materials structure.
\end{abstract}

Keywords: textbook,gender-based, character, learning materials

\section{PENDAHULUAN}

Buku ajar merupakan media transformasi ilmu pengetahuan dan nilai-nilai kehidupan kepada para siswa. Berkaitan de- ngan teori praktik, buku ajar menjadi arena siswa melakukan praktik internalisasi wacana doxa yang dianggap sebagai kebenaran. Di dalam buku ajar terkandung 
proses pengembangan potensi, pewarisan budaya, dan perpaduan antarkeduanya.

Karena berada dalam budaya patriarki, buku ajar tidak bisa lepas dari pengaruh budaya patriarki. Melalui buku ajar, kelompok ortodoksa membudayakan nilai patriarki yang dianggap sebagai wacana doksa. Kalimat yang digunakan dalam buku ajar sering kali mengkotak-kotakkan fungsi laki-laki dan perempuan sesuai nilai-nilai kepantasan tertentu yang berlaku di masyarakat, seperti pekerjaan yang lazim dikerjakan anak laki-laki dan pekerjaan yang lazim dikerjakan oleh anak perempuan.

Praktik konstruksi peran jender melalui buku ajar tersebut dipandang sebagai suatu kewajaran oleh masyarakat. Sebagai contoh dapat diamati pada Buku Siswa kelas I yang diterbitkan Kemendiknas (2013), bidang studi Bahasa Indonesia halaman 41 yaitu "Lani mencium bunga. Bunga harum baunya". Kalimat-kalimat di atas bersifat kategoris dan bernada manipulatif. Kalimat di atas mengkotakkotakkan kebiasaan laki-laki dan perempuan sesuai nilai-nilai kepantasan tertentu dalam masyarakat, yakni perempuan merupakan diri yang menyukai kelembutan seperti bunga.

Pada halaman tersebut juga dimunculkan gambar perempuan bermain boneka. Hal itu merupakan praktik konstruksi perempuan sebagai penguasa wilayah domistik, yakni harus bisa merawat boneka, sebagai wakil dari keluarga. Sementara itu, laki-laki sering ditampilkan bermain mobil-mobilan karena laki-laki merupakan penguasa arena publik yang harus menguasai alat transportasi agar memudahkan berkiprah di arena publik.

Keadaan di atas menjadi salah satu penunjang terbentuknya kesenjangan sosial. Kelompok dominan tanpa merasa bersalah sering melakukan marjinalisasi terhadap kelompok subordinat. Sebagaimana dikatakan oleh Pemerintah Republik Indonesia (2010:2) bahwa pembangunan karakter bangsa yang sudah diupayakan dengan berbagai bentuk, hingga saat ini belum terlaksana dengan optimal. Hal itu tecermin dari kesenjangan sosial-ekonomi-politik yang masih besar, kerusakan lingkungan yang terjadi di berbagai di seluruh pelosok negeri, masih terjadinya ketidakadilan hukum, pergaulan bebas dan pornografi yang terjadi di kalangan remaja, kekerasan dan kerusuhan, korupsi yang dan merambah pada semua sektor kehidupan masyarakat. Saat ini banyak dijumpai tindakan anarkis, konflik sosial, penuturan bahasa yang buruk dan tidak santun, dan ketidaktaataan berlalu lintas. Masyarakat Indonesia yang terbiasa santun dalam berperilaku, melaksanakan musyawarah mufakat dalam menyelesaikan masalah, mempunyai kearifan lokal yang kaya dengan pluralitas, serta bersikap toleran dan gotong royong mulai cenderung berubah menjadi hegemoni kelompok-kelompok yang saling mengalahkan dan berperilaku tidak jujur.

Sikap anarkis dalam masyarakat bisa dilihat dari fakta hilangnya sikap saling melindungi dan adanya pelecehan dalam masyarakat. Dampak dari praktik sosial dan gerakan feminisme banyak menimbulkan krisis identitas pada diri laki-laki dan perempuan. Sejalan dengan karakter maskulin yang mandiri, otonom, agresif, dan kompetitif, kemandirian perempuan membuat laki-laki merasa kurang dihargai. Dampaknya, tanpa disadari, rasa melindungi dan komitmen laki-laki terhadap perempuan semakin berkurang.

Agar siswa mampu melindungi diri dan menghargai orang lain, sekolah harus menanamkan nilai-nilai kesetaraan jender pada siswa. Agar bisa dimasukkan dalam kegiatan kurikuler, nilai-nilai jender tersebut dimasukkan dalam bidang studi bahasa Indonesia karena bidang studi ini bertujuan untuk membentuk siswa agar memiliki kemampuan berbahasa Indonesia yang baik dan benar serta dapat menghayati bahasa dan sastra Indonesia 
sesuai dengan situasi dan tujuan berbahasa serta tingkat pengalaman siswa Sekolah Dasar (Akhadiah dkk, 1991:1). Menurut BSNP (2006), tujuan pembelajaran bahasa Indonesia bagi siswa adalah untuk mengembangkan kemampuan berbahasa Indonesia sesuai dengan kemampuan, kebutuhan, dan minatnya, sedangkan bagi guru adalah untuk mengembangkan potensi bahasa Indonesia siswa, serta lebih mandiri dalam menentukan bahan ajar kebahasaan sesuai dengan kondisi lingkungan sekolah dan kemampuan siswa. Nuh (http://edukasi.kompas. com/read/2013/03/08/ 08205286/Kurikulum.2013) mengatakan bahwa usaha membentuk saluran sempurna (perfect channels dalam teknologi komunikasi) dapat dilakukan dengan menempatkan bahasa sebagai penghela mata pelajaranmata pelajaran lain. Dengan kata lain, kandungan materi mata pelajaran lain dijadikan sebagai konteks dalam penggunaan jenis teks yang sesuai dalam pelajaran Bahasa Indonesia. Melalui pembelajaran tematik integratif dan perumusan kompetensi inti, sebagai pengikat semua kompetensi dasar, pemaduan ini akan dapat dengan mudah direalisasikan.

Untuk mempermudah guru dan murid dalam memahami nilai-nilai kesetaraan jender tersebut dilakukan melalui pengembangan buku ajar yang merupakan buku pegangan untuk suatu bidang studi yang ditulis dan disusun oleh pakar bidang terkait dan memenuhi kaidah buku teks serta diterbitkan secara resmi dan disebarluaskan. Dalam praktik pembelajaran, buku ajar menjadi media dan arena pembelajaran. Sebagai media pembelajaran, buku ajar berperan sebagai alat bantu guru dalam melaksanakan kegiatan belajar mengajar di kelas. Sebagai arena pembelajaran, buku ajar terdiri atas materi yang harus disampaikan guru, penjelasan guru, dan evaluasi yang dilakukan guru. Melalui buku ajar, siswa dapat mengembangkan kompetensi diri secara mandiri sehingga guru dapat mengurangi kegiatannya menjelaskan pelajaran, memiliki banyak waktu untuk membimbing siswa dalam belajar atau membelajarkan siswa.

Agar bisa digunakan secara tepat, buku ajar harus dikembangkan dengan kondisi siswa. Hal itu karena siswa menjadi pelaku yang harus menjalankan "aturan main" yang berlaku dalam buku ajar tersebut. Buku ajar yang dikembangkan harus memberikan kesempatan siswa untuk membaca dan mempelajari konsepkonsep tanpa terbatas tempat dan waktu, baik secara individu ataupun berkelompok.

Melalui buku ajar pembelajaran bahwa Indonesia berbasis jender diharapkan agar terjadi praktik internalisasi self yang selama ini kurang diperhatikan orang tua. Dalam buku ajar harus terdapat pembelajaran tentang self, perbedaan self dan other dalam lingkungan sekolah dan masyarakat. Dengan cara tersebut diharapkan anak mempunyai pemahaman akan identitas diri dan keluarga, kondisi tubuhnya, pemahaman akan kondisi orang lain baik yang sejenis maupun lawan jenisnya, dan pemahaman tentang cara melindungi diri sehingga tidak terjadi kekerasan fisik maupun psikis.

Pengembangan buku ajar bahasa Indonesia berbasis jender perlu dilakukan karena dalam UU No. 20 tahun 2003 dinyatakan bahwa kesempatan pendidikan pada setiap satuan pendidikan tidak membedakan jenis kelamin, agama, suku, ras, kedudukan sosial, dan tingkat kemampuan ekonomi, dan tetap mengindahkan kekhususan satuan pendidikan yang bersangkutan. Dalam acuan operasional pengembangan kurikulum dinyatakan bahwa kurikulum bahasa Indonesia harus ditujukan untuk pengembangan peserta didik agar mengenal dirinya sebagai individu yang berbeda dengan individu lain. Untuk itu, pembelajaran bahasa Indonesia berbasis jender perlu dilaksanakan dalam 
rangka untuk penanaman pengetahuan maupun sikap jender sehingga terbentuk manusia Indonesia yang demokratis, berkeadilan, dan tidak diskriminatif. Hasil penelitian terdahulu menunjukkan bahwa masih terdapat "gap" antara kompetensi yang dimiliki guru dan kompetensi yang harus dimiliki guru dalam pengimplementasian pendidikan karakter berbasis jender dalam pembelajaran bahasa Indonesia SD. Guru SD banyak yang merasa kesulitan mengimplementasikan pendidikan karakter berbasis jender dalam pembelajaran bahasa Indonesia SD karena selama ini belum ada buku ajar bahasa Indonesia berbasis Jender.

Berdasarkan latar belakang di atas, kajian ini difokuskan pada (1) karakter yang dikembangkan dalam buku ajar bahasa Indonesia berbasis jender, (2) materi pembelajaran bahasa Indonesia berbasis jender, dan (3) struktur buku ajar bahasa Indonesia berbasis jender.

\section{METODE}

Penelitian ini menggunakan rancangan penelitian pengembangan. Model pengembangan yang digunakan adalah model Dick, Carey, dan Carey (2001) yang dimodifiasi berdasarkan keperluan pengembangan. Model ini mengarah pada upaya pemecahan masalah dan terpro- gram melanglui langkah-langkah kegiatan yang sistematis. Adapun langkahlangkah yang dilakukan dalam penelitian ini, yaitu: (1) menganalisis kurikulum sesuai dengan langkah-langkah Dick, Carey, dan Carey (2001) yang disajikan pada Gambar 1.; (2) mengidentifikasi struktur buku ajar; (3) mengembangkan draft buku ajar; (4) Melakukan proses pengkajian dan expert judgement draf buku ajar; dan merevisi buku ajar bahasa Indonesia SD untuk pengimplementasian pendidikan karakter berbasis jender.

Populasi penelitian ini adalah Sekolah Dasar di kota Malang yang berjumlah 250. Karena jumlahnya besar maka diadakan penyampelan dengan menggunakan teknik random sampling. Adapun sekolah yang dijadikan sampel ada 1 sekolah negeri dan 1 sekolah swasta. Adapun sekolah yang terpilih sebagai sampel adalah SDN Bareng 5 dan MI Sunan Gunungjati.

Dalam penelitian ini, peneliti berperan sebagai instrumen kunci dengan dibantu oleh angket dan pedoman wawancara. Teknik pengumpulan data yang digunakan dalam penelitian ini adalah observasi, angket, wawancara mendalam, dan focusing group discussion (FDG). Analisis data dilakukan secara kualitatif dan kuantitatif. Data yang berhasil dikumpulkan dianalisis dengan langkah-langkah se-

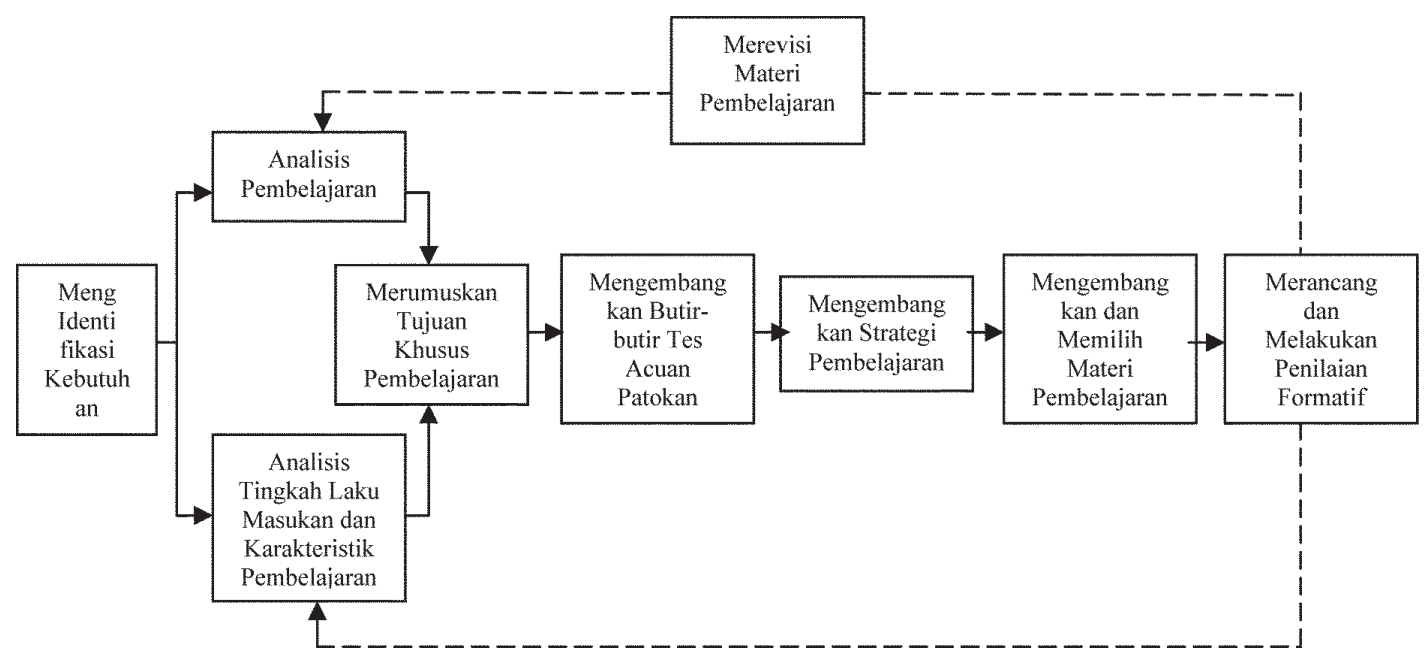

Gambar 1. Langkah-Langkah Pengembangan Model Dick, Carey, dan Carey (2001) 
bagai berikut. Pertama, telaah seluruh data yang diperoleh dari sumber data. Kedua, kategorikan dan klasifikasikan data sehingga tersusun struktur buku ajar dan draft buku ajar. Ketiga, refleksi data berdasarkan hasil evaluasi buku ajar melalui kegiatan pengkajian di lapangan dan expert judgement draft buku ajar. Keempat, kodifikasi data sebagai dasar pertimbangan untuk revisi buku ajar. Kelima, membuat simpulan hasil analisis berupa: (a) identifikasi struktur buku ajar, (b) draf buku ajar, (c) pengkajian dan expert judgement draf buku ajar, dan (d) revisi buku ajar bahasa Indonesia SD untuk pengimplementasian pendidikan karakter berbasis jender sehingga diperoleh buku ajar yang siap diuji coba lapangan.

\section{HASIL DAN PEMBAHASAN Karakter yang Dikembangkan dalam Buku Ajar Bahasa Indonesia Berbasis Jender}

Siswa merupakan makhluk sosial yang mempunyai keunikan tersendiri. Dengan segala keunikannya, siswa berusaha untuk menjalani perkembangannya menuju kesuksesannya. Mereka akan mengembangkan potensi dan kreatifitas yang dimilikinya untuk menyelaraskan diri dengan masyarakat. Dalam proses ini, oleh Bourdieau (1994) diistilahkan dengan praktik internalisasi eksterior dan eksternalisasi interior. Dalam praktik internalisasi eksterior, siswa menginternalisasi pajanan budaya yang ada di masyarakat sehingga menjadi habitus. Dalam praktik eksternalisasi interior, siswa memunculkan diri dengan habitusnya sebagai pelaku kehidupan di masayarakat.

Keunikan pembelajar tersebut harus dipahami oleh pelaku pendidikan, termasuk pengembang buku ajar. Melalui pemahaman tersebut diharapkan agar semua potensi yang dimiliki siswa bisa dikembangkan melalui praktik pembelajaran. Sebagaimana dinyatakan dalam Undang-Undang Sistem Pendidikan Na- sional tahun 2005, pendidikan nasional Indonesia merupakan sebuah upaya bersama antara semua elemen bangsa untuk membentuk individu yang mampu mengembangkan potensinya masingmasing, memiliki tanggung jawab sosial, berperilaku yang sesuai norma agama dan sosial yang berlaku, serta memiliki fungsi yang jelas dan bermanfaat di masyarakat.

Sebagai diri yang unik dengan karakter yang tidak sama, pengembang buku ajar harus mampu menjadikan bukunya sebagai arena siswa untuk mengembangkan potensi yang dimilikinya serta mencapai dan melaksanakan tugas-tugas perkembangannya. Dengan begitu, mereka dapat tumbuh dan berkembang sebagai individu yang mandiri dan produktif. Walaupun secara fisik mereka memiliki kemiripan, pada hakikatnya mereka tidaklah sama, baik dalam bakat, minat, kemampuan, dan sebagainya. Di samping itu, siswa juga merupakan makhluk yang sedang berkembang dengan irama perkembangan yang tidak sama. Untuk itulah mereka harus diberi kepercayaan secara positif agar mereka dapat menjalankannya dengan tanggung jawab.

Pengembang buku ajar dalam penelitian ini dimaksudkan untuk menciptakan arena yang mengeksternalisasi nilai-nilai karakter sehingga terbentuk pembelajar yang berkarakter. Jika arena sosial yang diciptakan salah, misalnya siswa diberi peran yang tidak sesuai dengan potensinya maka akan menimbulkan ketidakharmonisan antara apa yang diinginkan dengan apa yang menjadi tanggungjawabnya. Dampaknya, buku ajar menjadi arena yang tidak disukai siswa bahkan bisa menjadi beban bagi siswa. Dampaknya, siswa akan merasakan bahwa belajar melalui buku ajar hanya sekedar sarana untuk menjalankan tugas semata, ketimbang sebagai sebuah kegiatan menyenangkan yang memiliki nilai-nilai mulia. 
Sebagai praktik sosial, praktik konstruksi nilai-nilai mulia dapat dilakukan dalam berbagai arena. Di antaranya adalah bahasa. Dalam konteks pendidikan, bahasa bukanlah sekedar saluran tempat mengkomunikasikan informasi tentang keadaan mental, perilaku, atau fakta-fakta dunia ini, akan tetapi, bahasa merupakan arena yang menggerakkan dan akibatnya menyusun dunia sosial itu sendiri. Selain itu bahasa juga menata hubungan-hubungan dan struktur sosial. Perubahan-perubahan yang terjadi dalam wacana merupakan alat untuk mengubah dunia sosial. Perjuangan-perjuangan yang muncul pada tataran kewacanaan terjadi dalam upaya untuk mengubah maupun mereproduksi realitas sosial (Burdieau, 1994; Rusdiati. 2003, Sudiardja, 2004).

Dalam arena patriarki, jender berperan dalam membentuk karakter. Peran jender yang dikonstruk masyarakat menyebabkan laki-laki dan perempuan dengan sukarela menerima stereotipe yang menempel pada dirinya. Laki-laki akan menerima peran publik dirinya dan perempuan menerima peran domestik dirinya dengan segala ciri khasnya. Sebagaimana dikatakan oleh Holmes (2001:303) bahwa identitas jender ditunjukkan laki-laki dan perempuan melalui wacana mereka terhadap pengalaman personalnya. Sebagai contoh, ketika seorang perempuan ditanya tentang kesehatan ayahnya, dia bercerita tentang kegiatan yang dikerjakan sehari-harinya seperti bagaimana dia harus mengantar anaknya yang kecil berenang, menyuruh anak perempuannya yang besar untuk mempersiapkan makan siang kakeknya, dan juga bercerita bahwa hari itu dia juga telah mengunjungi ayahnya. Intinya, perempuan tersebut berusaha untuk memantapkan identitas jendernya. Identitas jender yang dibentuk adalah 'ibu yang baik' dan 'kewajiban anak perempuan'. Sebaliknya, ketika orang tua ditanya tentang anak laki-lakinya, dia akan menceritakan tentang kenakalan anak tersebut. Sebagai contoh, Ian, seorang anak laki-laki, melakukan kenakalan di rumah disikapi secara ganda yaitu 'anak laki-laki yang nakal' dan 'pahlawan". Dengan menggunakan frasa 'real monkey' dan 'little rascal' dengan disertai senyuman menunjukkan bahwa kenakalan disikapi dengan kasih sayang dan toleran, serta perilaku 'nakal' tersebut disikapi sebagai karakteristik wajar dari seorang anak laki-laki.

Berdasarkan argumen di atas, maka buku ajar bahasa Indonesia berbasis jender harus dikembangkan dan diarahkan untuk menjadi agen perubahan yang mampu menghantarkan siswa menemukan potensi dirinya sendiri dan memfasilitasi mereka untuk mencapai kepercayaan diri dalam mengembangkannya. Kemampuan bertahan hidup, yang di antaranya adalah kemampuan untuk memperoleh pekerjaan atau penghasilan yang layak hendaknya dipandang sebagai satu konsekuensi alami dari keberhasilan penemuan dan pengembangan potensi dan kepercayaan diri tersebut. Dari sini jelas, semakin banyaknya orang yang dapat menemukan potensinya masingmasing akan berdampak pada terciptanya sebuah masyarakat dengan karakter hightrust dan lebih mengedepankan ciri kolektivitas dalam berpikir dan bertindak.

Melalui pengembangan buku paket bahasa Indonesia berbasis jender ini diharapkan agar budaya permisif dan penghargaan terhadap kelompok dominan tidak akan berkembang. Di dalam diri siswa akan terinternalisasi nilai-nilai karakter tanpa terasa ada paksaan. Melalui buku paket bahasa Indonesia berbasis jender dikembangkan karakter siswa yang mampu: (1) mengakses semua kegiatan tanpa membedakan jenis kelamin, (2) mengomunikasikan kepercayaan disertai alasan yang mendasarinya, (3) memperlakukan diri dan orang lain secara adil, (4) berpartisipasi aktif dalam praktik kehidupan, (5) menghargai pandangan 
orang lain, (6) mengemukakan keraguraguan atau perasaan tidak percaya disertai dengan alasan dan rasa hormat, (7) mempunyai peran kontrol dalam bentuk keberanian menyampaikan nilai-nilai yang dikehendaki dan tidak dikehendaki, (8) membuat dan menerapkan aturan secara konsekuen dengan disertai alasan, (9) memanfaatkan praktik pembelajaran untuk menciptakan pengalaman sosial dan emosional, (10) mampu berkomuniasi dengan orang yang berbeda pendapat, dan (11) memberikan kebebasan kepada orang lain untuk perilaku secara berbedabeda.

\section{Materi Pembelajaran Bahasa Indonesia Berbasis Jender}

Sebagai buku penunjang buku paket bahasa Indonesia Sekolah Dasar kelas I, materi pembelajaran bahasa Indonesia berbasis jender dikembangkan sesuai dengan tema yang dikembangkan dalam kurikulum 2013. Dengan begitu, isi buku ajar sesuai dengan tujuan nasional pendidikan, tujuan institusional, dan tujuan kurikuler.

Dalam kurikulum 2013, tema yang dikembangkan dalam bidang studi Bahasa Indonesia kelas I adalah: (1) diriku, (2) kegemaranku, (3) kegiatanku, (4) keluargaku. (5) pengalamanku, (6) lingkungan bersih, sehat, dan asri, (7) benda, hewan, dan tanaman di sekitarku, dan (8) peristiwa alam. Tema-tema tesebut selanjutnya dikembangkan menjadi sub tema dan sub-subtema.

Setelah dilakukan pengembangan tema, selanjutnya dikembangkan nilainilai jender yang didasarkan pada hasil operasionalisasi konsep PUG yang dikembangkan oleh kementerian PU, yakni: (1) akses dalam kegiatan pembelajaran siswa laki-laki dan perempuan, (2) partisipasi siswa laki-laki dan perempuan dalam pelaksanaan praktik pembelajaran, (3) kontrol terhadap sarana dan prasarana yang ada di sekolah sehingga dapat melakukan proses pembelajaran dengan baik, dan (4) manfaat pembelajaran untuk keperluan masa depan siswa laki-laki dan perempuan.

Agar dapat masuk dalam mata pelajaran bahasa Indonesia dengan tepat, hasil analisis tema dan nilai-nilai jender tersebut disesuaikan dengan KI mata pelajaran bahasa Indonesia kurikulum 2013. Adapun KI mata pelajaran bahasa Indonesia kelas I SD dalam kurikulum 2013 adalah sebagai berikut. Pertama, menerima dan menjalankan ajaran agama yang dianutnya. Kedua, memiliki perilaku jujur, disiplin, tanggung jawab, santun, peduli, dan percaya diri dalam berinteraksi dengan keluarga, teman, dan guru. Ketiga, memahami pengetahuan faktual dengan cara mengamati, mendengar, melihat, membaca, dan menanya berdasarkan rasa ingin tahu tentang dirinya, makhluk ciptaan Tuhan dan kegiatannya, dan benda-benda yang dijumpainya di rumah dan di sekolah. Keempat, menyajikan pengetahuan faktual dalam bahasa yang jelas dan logis, dalam karya yang estetis, dalam gerakan yang mencerminkan anak sehat, dan dalam tindakan yang mencerminkan perilaku anak beriman dan berakhlak mulia.

Dengan mendasarkan pada nilai-nilai jender, tema, dan KI, selanjutnya dikembangkan materi pokok bahasa Indonesia. Materi pokok tersebut dikembangkan sesuai dengan karakter mata pelajaran bahasa Indoneisia dalam kurikulum 2013. Pertama, materi yang dijarkan ditekankan pada kompetensi berbahasa sebagai alat komunikasi untuk menyampaikan gagasan dan pengetahuan. Kedua, siswa dibiasakan membaca dan memahami makna teks serta meringkas dan menyajikan ulang dengan bahasa sendiri. Ketiga, siswa dibiasakan menyusun teks yang sistematis, logis, dan efektif melalui latihan-latihan penyusunan teks. Keempat, siswa dikenalkan dengan aturan-aturan teks yang sesuai sehingga tidak rancu

Buku Ajar Bahasa Indonesia Berbasis Jender Sebagai Media Pengembangan Karakter Siswa 
dalam proses penyusunan teks (sesuai dengan situasi dan kondisi: siapa, apa, dimana). Kelima, siswa dibiasakan untuk dapat mengekspresikan dirinya dan pengetahuannya dengan bahasa yang meyakinkan secara spontan.

Setelah materi pokok tersusun, selanjutnya dikembangkan alat penilaian yang digunakan untuk menilai ketercapaian pembelajaran. Alat penilain tersebut disesuaikan dengan tujuan pembelajaran yang ingin dicapai dalam kurilum 2013.

\section{Struktur Buku Ajar Bahasa Indonesia Berbasis Jender}

Selama ini, banyak penulis buku yang hanya mementingkan penyampaian materi pembelajaran. Sebagaimana disampaikan oleh Pusat Perbukuan (2004:25) bahwa buku teks terbitan swasta ditemukan bahwa rata-rata hanya $50 \%$ buku teks pelajaran yang memenuhi syarat untuk digunakan di sekolah. Salah satu alasannya adalah karena buku ajar tersebut masih berfokus pada materi.

Hasil penelitian ini berupa buku ajar dengan struktur tampilan yang diusahakan menarik perhatian siswa. Dengan tampilan yang dibuat diharapkan agar buku ajar tersebut mampu membuat siswa ingin selalu membaca baik ketika bersama guru ataupun tidak. Untuk itu, buku ajar tersebut disusun dengan memperhatikan kesesuaian antara materi dan tataan materinya. Dalam Buku Panduan Pengembangan Bahan Ajar (Depdiknas, 2008) dinyatakan bahwa beberapa hal yang harus diperhatikan dalam penyusunan buka ajar adalah: (1) Struktur Tampilan, (2) Struktur Bahasa, (3) Keterpahaman, (4) Struktur Stimulan, (5) Struktur teks (Keterbacaan), dan (6) Struktur Materi Instruksional.

Strukutur tampilan untuk pengorganisasian isi bahan ajar disusun secara berurutan mulai dari sampul, kata pengantar, daftar isi, petunjuk penggunaan, kompetensi yang harus dikuasai siswa, isi bahan ajar, dan daftar rujukan. Stuktur tampilannya juga harus memperhatikan kesetaraan jender dan ras.

Struktur bahasa dalam buku ajar ini adalah kosakata, kalimat, hubungan antarkalimat, kepaduan paragraf dipilih untuk kepentingan pembentukan karakter serta tidak memicu munculnya kesenjangan jender. Bahasa yang digunakan adalah ragam formal, komunikatif, dan logis.

Struktur keterpahaman dikembangkan dengan memperhatikan usia fisik dan psikologis siswa. Dalam penelitian ini, karena buku digunakan untuk kelas I, dalam buku banyak terdapat drill untuk meningkatkan kemampuan membaca siswa. Selain itu, fakta kehidupan yang dikembangkan lebih banyak mengarah pada kehidupan pribadi, keluarga, dan teman sebaya.

Struktur stimulasi dikembangkan dengan memperhatikan aspek visual, kognitif, auditoris. Aspek visual dikembangkan dengan menggunakan gambar, warna, dan garis. Aspek kognitif dikembangkan sesuai dengan hasil pemetaan KI dan KD. Aspek auditoris dikembangkan dengan latihan yang lebih mengarah pada kegiatan mengeluarkan bunyi-bunyi bahasa yang memancing siswa untuk mengenal bunyi-bunyi bahasa di sekitarnya.

Struktur teks dikembangkan dengan memperhatikan bentuk dan ukuran huruf, topografi, logika. Teks ditampilkan dengan diberi gambar pendukung. Dengan struktur teks tersebut diharapkan agar siswa merasa nyaman ketika belajar.

Struktur materi disesuaikan dengan hasil analisis materi, di dalamnya terdapat fakta kehidupan dalam bentuk cerita, pembahasan, latihan, serta evaluasi. Perlunya disajikan fakta terlebih dahulu karena sesuai dengan anak usia SD yang lebih banyak menginternalisasi nilai-nilai dari interaksi dengan lingkungan sosialnya, seperti teman bermain dan belajar baik di rumah maupun sekolah. 


\section{SIMPULAN}

Berdasarkan temuan penelitian, dikemukakan hasil penelitian sebagai berikut. Pertama, karakter yang dikembangkan dalam buku ajar bahasa Indonesia berbasis jender adalah siswa yang mampu (1) mengakses semua kegiatan tanpa membedakan jenis kelamin, (2) mengomunikasikan kepercayaan disertai alasan yang mendasarinya, (3) memperlakukan diri dan orang lain secara adil, (4) berpartisipasi aktif dalam praktik kehidupan, (5) menghargai pandangan orang lain, (6) mengemukakan keragu-raguan atau perasaan tidak percaya disertai dengan alasan dan rasa hormat, (7) mempunyai peran kontrol dalam bentuk keberanian menyampaikan nilai-nilai yang dikehendaki dan tidak dikehendaki, (8) membuat dan menerapkan aturan secara konsekuen dengan disertai alasan, (9) memanfaatkan praktik pembelajaran untuk menciptakan pengalaman sosial dan emosional, (10) mampu berkomuniasi dengan orang yang berbeda pendapat, (11) memberikan kebebasan kepada orang lain untuk perilaku secara berbeda-beda.

Kedua, materi pembelajaran bahasa Indonesia berbasis jender dikembangkan sesuai dengan nilai-nilai jender dan nilai-nilai matapelajaran bahasa Indonesia. Nilai-nilai jender didasarkan pada hasil operasionalisasi konsep PUG yang dikembangkan oleh kementerian PU. Nilai-nilai bahasa Indonesia didasarkan pada tema, KI, dan KD, dan materi pokok mata pelajaran bahasa Indonesia dalam kurikulum 2013. Ketiga, struktur buku ajar bahasa Indonesia berbasis jender harus memperhatikan: (1) Struktur Tampilan, (2) Struktur Bahasa, (3) Keterpahaman, (4) Struktur Stimulan, (5) Struktur teks (Keterbacaan), dan (6) Struktur Materi Instruksional.

\section{UCAPAN TERIMA KASIH}

Artikel ini disusun berdasarkan hasil penelitian yang dilaksanakan pada tahun
2013 dengan dukungan anggaran DIPA dalam rangka pelaksanaan penugasan penelitian Desentralisasi Tahun Anggaran 2014 Nomor SP-DIPA:023.04.2.415015/2014 Tanggal 05 Desember 2013, Nomor SP2H: 043/SP2H/P/K7/KM/2014, Tanggal 03 April 2014. Ucapan terima kasih disampaikan kepada Lembaga Penelitian UM yang telah memfasilitasi penelitian ini. Kepala Sekolah dan guru SD kota Malang yang telah bersedia menjadi objek penelitian serta membantu penelitian dalam kegiatan FGD.

\section{DAFTAR PUSTAKA}

Akhadiah, S. Dkk. 1991. Pembinaan Kemampuan Menulis Bahasa Indonesia. Jakarta: Erlangga

BNSP. 2006. Panduan Penyusunan Kurikulum Tingkat Satuan Pendidikan Jenjang Pendidikan Dasar dan Menengah. Jakarta: Depdiknas

Bourdieu, Pierre. 1994. Language and Symbolic Power. Cambridge, Massachusetts: Harvard University Press.

Departemen Pendidikan Nasional. 2004. UU No. 20 tahun 2003 tentang Sistem Pendidikan Nasional. Jakarta: Departemen Pendidikan Nasional.

Dick, W., Carey, L., \& Carey, J. O. 2001. The Systematic Design of Instruction (5th ed.). New York: Addison-Wesley, Longman.

Direktorat Pembinaan Sekolah Menengah Atas. 2008. Panduan Pengembangan Bahan Ajar. Jakarta: Departemen Pendidikan Nasional.

Holmes, J. 2001. An Introduction to Sociolinguistics. London: Longman.

Kemendikbud. 2014. Konsep dan Implementasi Kurikulum 2013. Jakarta: Kementerian Pendidikan dan Kebudayaan.

Kemendiknas. 2013. Peraturan Menteri Pendidikan Dan Kebudayaan Nomor 54 Tahun 2013 tentang Standar Kompetensi Lulusan Pendidikan Dasar dan Menengah. Jakarta: Kemendiknas 
Kemendiknas. 2013. Peraturan Menteri Pendidikan dan Kebudayaan Nomor 64 Tahun 2013 tentang Standar Isi Pendidikan Dasar dan Menengah. Jakarta: Kemendiknas

Kemendiknas. 2013. Peraturan Menteri Pendidikan Dan Kebudayaan Nomor 67 Tahun 2013 tentang Kerangka Dasar dan Struktur Kurikulum Sekolah Dasar/Madrasah Ibtidaiyah. Jakarta: Kemendiknas

Nuh, M. 2013. Kurikulum 2013. http://edukasi.kompas.com/ $\mathrm{read} / 2013 / 03 / 08 / 08205286 /$ Kurikulum.2013. Diunduh tanggal 5 Maret 2014.

Pusat Perbukuan. 2004. Model Buku Pelajaran Bahasa Inggris. Jakarta: Depdiknas.

Pusat Perbukuan. 2002. Pedoman Pengembangan Standar Perbukuan. Jakarta: Depdiknas
Rusdiarti, S. R. 2003. Bahasa, Pertarungan Simbolik dan Kekuasaan, dalam $B A$ SIS No. 11-12 Desember 2003

Rusidi. 2009. Undang-Undang Sistem Pendidikan Nasional (Pendidikan Umum dan Pendidikan Keagamaan). Jakarta: CV. Naga Jawa Berdikari.

Reiser, Robert A., dan John V. Zdemsey. 2007. Trends and issues Instructional Design and Technology. London: PEARSON

Riana. A. 2012. Tumbuhkan Toleransi Anak Melalui Kurikulum 2013. http://edukasi.Kompas.com/ $\mathrm{read} / 2012 / 12 / 22 / 11420525 /$ Tumbuhkan.Toleransi.Anak.melalui.Kurikulum.2013. diakses 25 Pebruari 2013. Pukul 22.19.

Sudiarja, A. 2004. "Tanpa Kemampuan Komunikatif, Masyarakat Hancur". Basis. No. 11-12, Tahun ke-53. November-Desember 2004. 
Lampiran:

Contoh Pengembangan Materi Buku Ajar Bahasa Indonesia Berbasis Jender

\section{TEMA 1 DIRI SENDIRI \\ SUB TEMA 1: IDENTITASKU}

\begin{tabular}{|c|c|c|c|c|}
\hline $\begin{array}{l}\text { KOMPETENSI } \\
\text { JENDER }\end{array}$ & $\begin{array}{l}\text { SUB-SUB } \\
\text { TEMA }\end{array}$ & $\begin{array}{l}\text { KOMPETENSIYANG } \\
\text { DIKEMBANGKAN }\end{array}$ & MATERI POKOK & PENILAIAN \\
\hline $\begin{array}{l}\text { Pembelajaran } 1 \\
\text { Akses }\end{array}$ & $\begin{array}{l}\text { Pengenalan } \\
\text { identitas diri }\end{array}$ & $\begin{array}{l}\text { KI } 1 \text { (Sikap Spiritual) } \\
\text { Menerima dan menjalankan ajaran } \\
\text { agama yang dianutnya } \\
\text { Menerima anugerah Tuhan Yang Maha } \\
\text { Esa berupa bahasa Indonesia yang } \\
\text { dikenal sebagai bahasa persatuan dan } \\
\text { sarana belajar di tengah keberagaman } \\
\text { bahasa daerah } \\
\text { KI } 2 \text { (Sikap Sosial) Menunjukkan } \\
\text { perilaku jujur, disiplin, tanggung jawab, } \\
\text { santun, peduli, dan percaya diri dalam } \\
\text { berinteraksi dengan keluarga, teman, } \\
\text { dan guru } \\
\text { Memiliki rasa percaya diri terhadap } \\
\text { keberadaan tubuh melalui } \\
\text { pemanfaatan bahasa Indonesia } \\
\text { dan/atau bahasa daerah } \\
\text { KI } 3 \text { (Pengetahuan) Memahami } \\
\text { pengetahuan faktual dengan cara } \\
\text { mengamati [mendengar, melihat, } \\
\text { membaca] dan menanya berdasarkan } \\
\text { rasa ingin tahu tentang dirinya, } \\
\text { makhluk ciptaan Tuhan dan } \\
\text { kegiatannya, dan benda-benda yang } \\
\text { djiumpainya di } \\
\text { rumah dan di sekolah } \\
\text { Mengenal teks cerita diri/personal } \\
\text { tentang keberadaan keluarga dengan } \\
\text { bantuan guru atau teman dalam } \\
\text { bahasa Indonesia lisan dan tulis yang } \\
\text { dapat diisi dengan kosakata bahasa } \\
\text { daerah untuk membantu pemahaman } \\
\text { KI } 4 \text { (Keterampilan) Menyajikan } \\
\text { pengetahuan faktual dalam bahasa } \\
\text { yang jelas dan logis, dalam karya yang } \\
\text { estetis, dalam gerakan yang } \\
\text { mencerminkan anak sehat, dan dalam } \\
\text { tindakan yang mencerminkan perilaku } \\
\text { anak beriman dan berakhlak mulia } \\
\text { Menyampaikan teks cerita diripersonal } \\
\text { tentang keluarga secara mandiri dalam } \\
\text { bahasa Indonesia lisan dan tulis yang } \\
\text { dapat diisi dengan kosakata bahasa } \\
\text { daerah untuk membantu penyajiian }\end{array}$ & $\begin{array}{l}\text { Tanggapan secara } \\
\text { nonverbal terhadap } \\
\text { informasi yang } \\
\text { didengarkan } \\
\text { Kalimat sederhana } \\
\text { untuk } \\
\text { memperkenalkan diri } \\
\text { Kalimat sederhana } \\
\text { Label nama }\end{array}$ & $\begin{array}{l}\text { Observasi } \\
\text { Tes praktek } \\
\text { Unjuk kerja } \\
\text { Pemberian } \\
\text { tugas }\end{array}$ \\
\hline $\begin{array}{l}\text { Pembelajaran } 2 \\
\text { Partisipasi }\end{array}$ & $\begin{array}{l}\text { Peran díri } \\
\text { dalam Kelas }\end{array}$ & $\begin{array}{l}\text { KI } 1 \text { (Sikap Spiritual) } \\
\text { Menerima dan menjalankan ajaran } \\
\text { agama yang dianutnya } \\
\text { Menerima anugerah Tuhan Yang Maha } \\
\text { Esa berupa bahasa Indonesia yang } \\
\text { dikenal sebagai bahasa persatuan dan } \\
\text { sarana belajar di tengah keberagaman } \\
\text { bahasa daerah }\end{array}$ & $\begin{array}{l}\text { Pelafalan bunyi } \\
\text { bahasa } \\
\text { Kalimat sapaan } \\
\text { Gambar seri } \\
\text { garis lurus }\end{array}$ & $\begin{array}{l}\text { Observasi } \\
\text { Tes praktek } \\
\text { Unjuk kerja } \\
\text { Pemberian } \\
\text { tugas }\end{array}$ \\
\hline
\end{tabular}

Buku Ajar Bahasa Indonesia Berbasis Jender Sebagai Media Pengembangan Karakter Siswa 
KI 2 (Sikap Sosial) Menunjukkan perilaku jujur, disiplin, tanggung jawab, santun, peduli, dan percaya diri dalam berinteraksi dengan keluarga, teman, dan guru

Memiliki rasa percaya diri terhadap

keberadaan tubuh melalui

pemanfaatan bahasa Indonesia

dan/atau bahasa daerah

KI 3 (Pengetahuan) Memahami

pengetahuan faktual dengan cara mengamati [mendengar, melihat, membaca] dan menanya berdasarkan rasa ingin tahu tentang dirinya, makhluk ciptaan Tuhan dan kegiatannya, dan benda-benda yang dijumpainya di rumah dan di sekolah

Mengenal teks cerita diri/personal tentang keberadaan keluarga dengan bantuan guru atau teman dalam bahasa Indonesia lisan dan tulis yang dapat diisi dengan kosakata bahasa daerah untuk membantu pemahaman KI 4 (Keterampilan) Menyajikan pengetahuan faktual dalam bahasa yang jelas dan logis, dalam karya yang estetis, dalam gerakan yang mencerminkan anak sehat, dan dalam tindakan yang mencerminkan perilaku anak beriman dan berakhlak mulia Menyampaikan teks cerita diri/personal tentang keluarga secara mandiri dalam bahasa Indonesia lisan dan tulis yang dapat diisi dengan kosakata bahasa daerah untuk membantu penyajian

\begin{tabular}{|c|c|c|c|c|}
\hline $\begin{array}{l}\text { Pembelajaran } 3 \\
\text { Kontrol }\end{array}$ & $\begin{array}{l}\text { Peran diri } \\
\text { dalam } \\
\text { masyarakat } \\
\text { (Memperkenalk } \\
\text { an } \\
\text { nama,alamat, } \\
\text { nama orang } \\
\text { tua, nama } \\
\text { saudara inti) }\end{array}$ & $\begin{array}{l}\text { KI } 1 \text { (Sikap Spiritual) } \\
\text { Menerima dan menjalankan ajaran } \\
\text { agama yang dianutnya } \\
\text { Menerima anugerah Tuhan Yang Maha } \\
\text { Esa berupa bahasa Indonesia yang } \\
\text { dikenal sebagai bahasa persatuan dan } \\
\text { sarana belajar di tengah keberagaman } \\
\text { bahasa daerah } \\
\text { KI } 2 \text { (Sikap Sosial) Menunjukkan } \\
\text { perilaku jujur, disiplin, tanggung jawab, } \\
\text { santun, peduli, dan percaya diri dalam } \\
\text { berinteraksi dengan keluarga, teman, } \\
\text { dan guru } \\
\text { Memiliki rasa percaya diri terhadap } \\
\text { keberadaan tubuh melalui } \\
\text { pemanfaatan bahasa Indonesia } \\
\text { dan/atau bahasa daerah } \\
\text { KI } 3 \text { (Pengetahuan) Memahami } \\
\text { pengetahuan faktual dengan cara } \\
\text { mengamati Imendengar, melihat, } \\
\text { membaca] dan menanya berdasarkan } \\
\text { rasa ingin tahu tentang dirinya, } \\
\text { makhluk ciptaan Tuhan dan } \\
\text { kegiatannya, dan benda-benda yang } \\
\text { dijumpainya di } \\
\text { rumah dan di sekolah }\end{array}$ & $\begin{array}{l}\text { Tanggapan secara } \\
\text { nonverbal terhadap } \\
\text { informasi yang } \\
\text { didengarkan } \\
\text { Gambar tunggal dan } \\
\text { gambar seri } \\
\text { Suku kata } \\
\text { Kata }\end{array}$ & $\begin{array}{l}\text { Observasi } \\
\text { Tes praktek } \\
\text { Unjuk kerja } \\
\text { Pemberian } \\
\text { tugas }\end{array}$ \\
\hline
\end{tabular}

LITERA, Volume 14, Nomor 2, Oktober 2015 


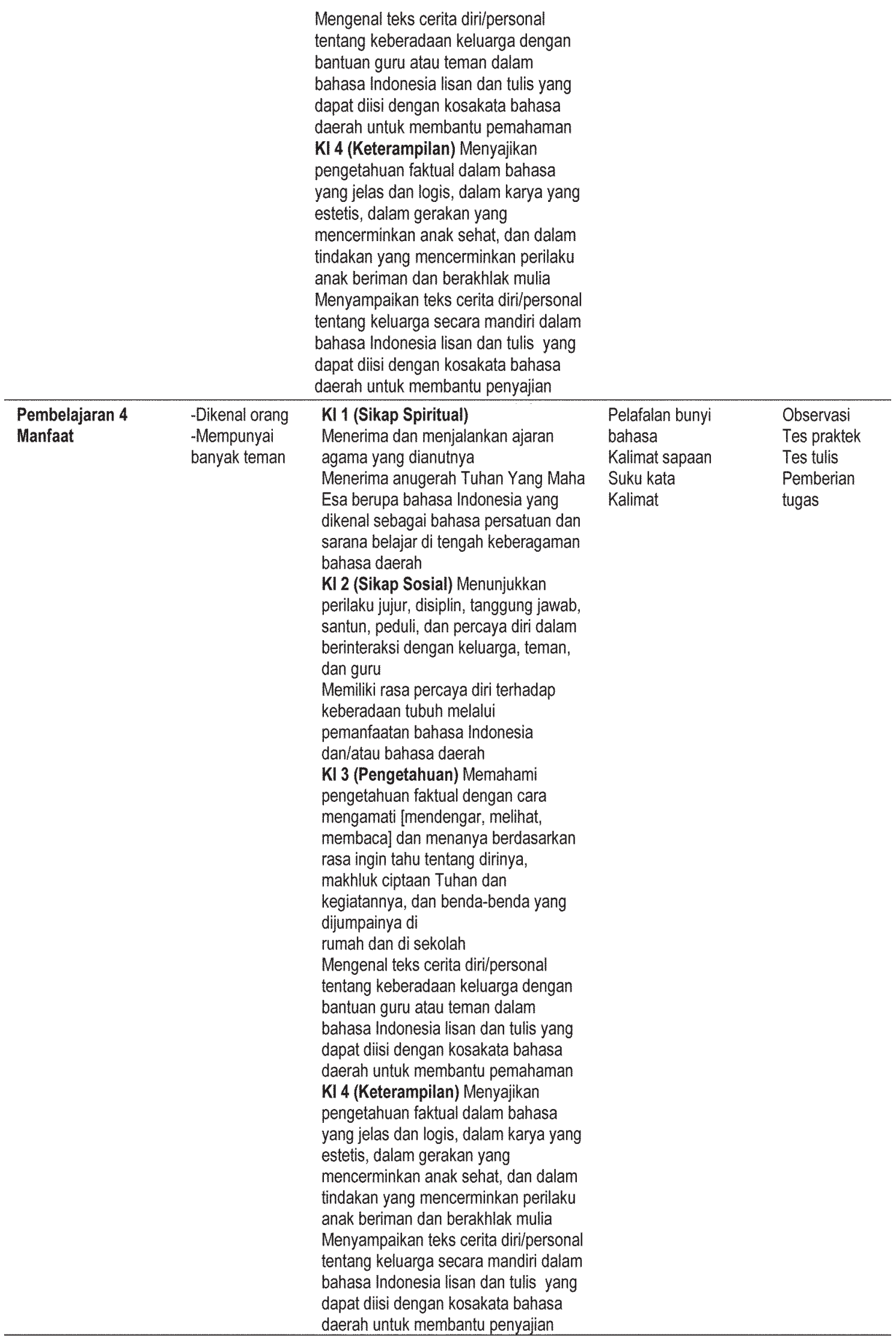

Buku Ajar Bahasa Indonesia Berbasis Jender Sebagai Media Pengembangan Karakter Siswa 